\title{
Climate vulnerability scenario of the agri-fishery communities in the Bicol
}

\section{River Basin, Philippines}

\author{
Ricky P. Laureta ${ }^{1 *}$, Ric Ryan H. Regalado ${ }^{1}$, Ermar B. De La Cruz ${ }^{2}$ \\ ${ }^{1}$ Partido State University, Goa, Camarines Sur 4422, Philippines \\ 2Planning, Monitoring and Evaluation Division, Department of Agriculture Regional Field Office 5, \\ Pili, Camarines Sur 4418, Philippines \\ *Corresponding author: da5.bicolriverproject@parsu.edu.ph
}

\begin{abstract}
This paper investigated the vulnerability of the agriculture sector and rural agri-fishery livelihoods in the Bicol River Basin (BRB) in the Philippines to projected changes in climate. The geographical characteristics of the BRB features eight major sub-basins or watersheds consisting of Libmanan-Pulantuna, Ragay Hills, Thiris, Naga-Yabo, Pawili River, Waras-Lalo, Naporog, and Quinali. The study adopted the Climate Risk Vulnerability Assessment (CRVA) which employed geospatial modelling through the use of geographic information systems (GIS) data, briefly, a number of indicators which are presumed to affect vulnerability were used including exposure, sensitivity, and adaptive capacity which were aggregated to provide an index of vulnerability. These components were integrated and modelled using GIS by identifying exposure to natural hazards, assessing the sensitivity of major crops to climate variations using ecological model (MaxEnt) under high emission climate scenario (RCP8.5), and identifying key aspects of adaptive capacity. Additionally, we also analyzed the perception of stakeholders towards vulnerability using participatory approaches. This enabled us to identify areas of exposure and vulnerability, and pointed areas of greatest need for strengthened adaptive capacity and risk management. Our findings suggested that majority of the towns in the north and central portions of the BRB will largely experience increased vulnerability, particularly, in the Thiris sub-basin including some parts of Ragay Hills, WarasLalo and the northwestern Libmanan-Pulantuna sub-basins. On the contrary, the entire Quinali sub-basin in the south revealed to have the lowest vulnerability index. The information derived from the study can be utilized to reinforce local-based climate policies.
\end{abstract}

Keywords: Bicol River Basin, Climate Risk Vulnerability Assessment, Geographic Information Systems, Vulnerability, Agri-fishery communities, Philippines

\section{Introduction}

Known for its agricultural capacities, the Philippines' physiographic and topographic characteristics where exposure to different abiotic stresses such as extreme solar radiation, sea level rise and ill-effects of meteorological-related hazards (Doroteo 2015; Mascariñas et al., 2013; World Bank, 2013; Peñalba, et al., 2012) are mostly experienced, has long posed a substantial amount of concern and significant impact on the spatial and temporal aspects of agricultural productivity. The erratic climate variability and extremes in the country are known to be largely modulated by the
El Niño-Southern Oscillation, or ENSO, an interannual perturbation of the climate system characterized by variations in the temperature of the surface water and air surface pressure of the eastern and western Pacific Ocean, respectively, which in turn creates a pronounced effect on agricultural productivity (Stuecker, et al. 2018; Alberto, et al. 2012). Although the effects of climate change, some of which can be attributed to anthropogenic climate change, are expected to vary geographically, poor and vulnerable small-scale farmers can expect increases in the volatility of weather patterns, severe weather events (including increased drought and flood risk), and 


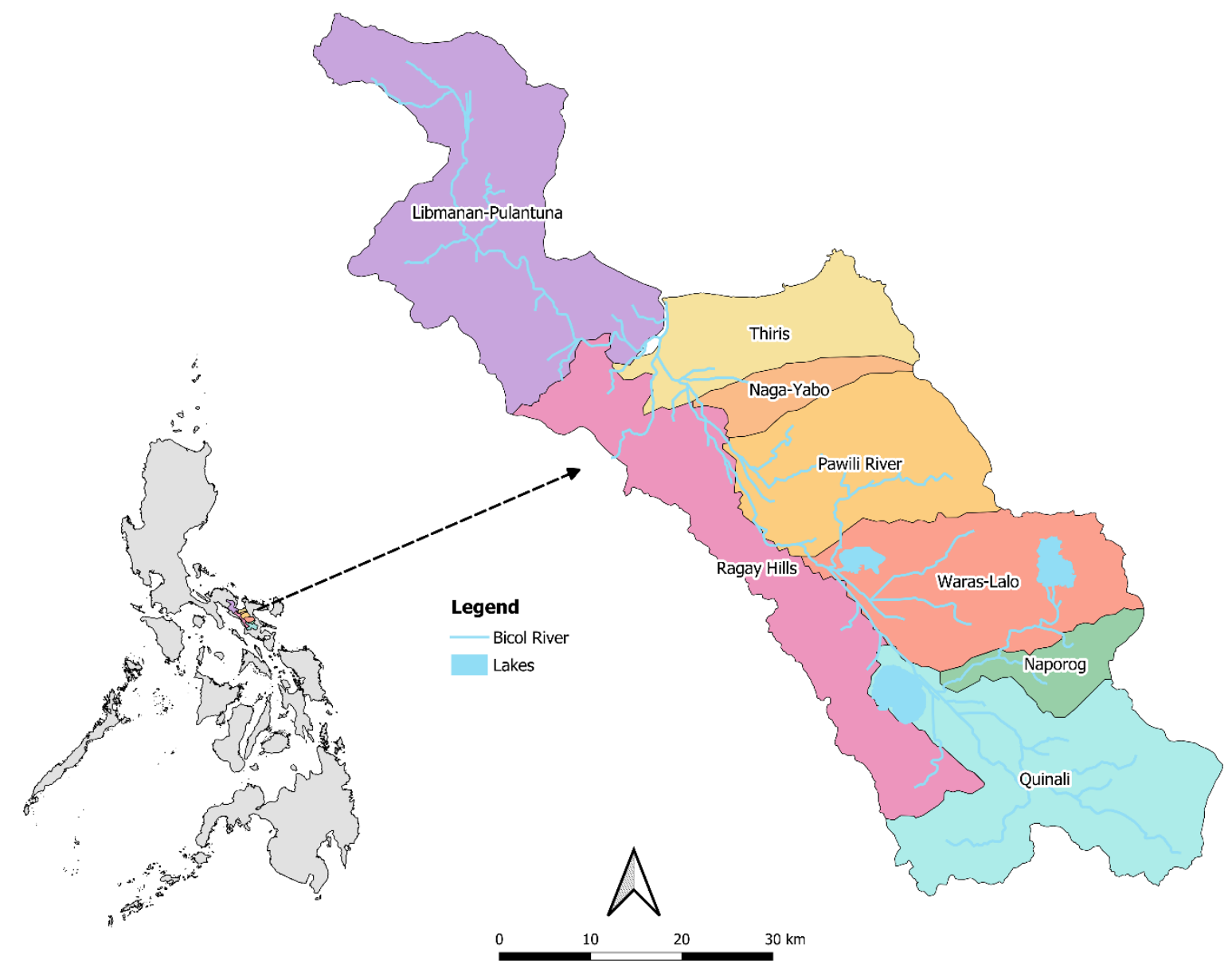

Figure 1. The Bicol River Basin area showing the eight major sub-basins that constitutes its general geographical characteristics.

increases in mean temperature and rising sea levels (Jost et al., 2015) especially in a meteorologically hazard-prone country like the Philippines.

Identifying climate change vulnerability requires a clear conceptual framework and in order to strengthen the capacities of selected communities in the Philippines, a preliminary identification and situational assessment of the areas most vulnerable to climate change risks is the primary task to be done in order to gather baseline information about the communities' vulnerability and the factors determining them.

Here, we provide a vulnerability assessment of one of the major river basins in the Philippine archipelago. The Bicol River Basin (BRB) has a total land area of 317,103 hectares and largely embraces the central portion of Camarines Sur, the northern portion of Albay, and a portion of Camarines Norte provinces in the Bicol region. Figure 1 shows the location map of the Bicol River Basin and the eight (8) sub-basins or watersheds that constitutes its general geographical characteristics. The distinct geo-morphological features found in the area include major geologic formations, which allows it to be naturally divided into: the Bicol Plain, the Sedimentary Terrain on its southwestern side and Volcanic Terrain found on the eastern rim bounded by a cordillera of five volcanic mountains of which one, the Mayon Volcano is active. The basin plays a crucial role in the development of the region because of the abundant resources within it and the ecological services it provides to support the livelihood of communities. About $77 \%$ of the basin area or 243,800 hectares are cultivated agricultural lands, its rivers and lakes provide irrigation water to these lands, apart from being used for fishing. The forests and forestlands, including protected areas, contain rich biodiversity resources and non- 
timber products, which are used as raw materials for handicrafts. The major rivers and tributaries of the BRB, likewise, provide sources of water for irrigation, domestic use and power generation (DENR, 2015). With the vast area covered by the river, millions of pesos $(\mathrm{PhP})$ in damage in agriculture and fisheries are experienced perennially by the communities living along it, largely due to climate change.

To date, the majority of studies (Herrin, 2019: Rola, et al., 2018: DENR, 2015: Abon, et al., 2012: Meigh \& Bartlett, 2010: Usamah \& Alkema, 2006) conducted in the BRB are mostly limited to socio-economic profiling and analyses, inventory of biophysical resources, hazard-risk assessments, management regimes and/or the combinations thereof. We also noted that, most of the literature archives are already outdated spanning from the 1970's-1990's. Motivated by these considerations, we employed a contemporary and comprehensive Climate Risk Vulnerability Assessment (CRVA) framework following latest geospatial modelling through the use of GIS data, and selected crops used for the ecological modelling and their interaction within the spatial model structure to assess vulnerability and the components that is closely interlinked with it. We also investigated the main hotspots of vulnerability and the underlying driving factors using conventional participatory social research methods. Since river basins are documented to be highly susceptible to climate change (Dilshad et al., 2019; Johnson \& Hutton, 2014; Gohari et al., 2013), the aim was to provide a clear visualization of the current climate scenario of the vulnerable agri-fishery communities living within the Bicol River Basin in order to identify at administrative level which areas are most vulnerable to the projected impacts of climate change on agriculture and recommend interventions for future policy directions.

\section{Methods}

In this section the framework and models used for assessing the vulnerability on the agri-fisheries sector are presented. Vulnerability was assessed by aggregating two climate scenarios namely baseline/current scenario and the projected (2050) scenario. Moreover, the participatory approach in assessing the stakeholders' perception towards vulnerability was likewise discussed.

2.1. Study area. The Bicol River Basin (BRB) is an integrated watershed resource that geographically extends from $13^{\circ} 0^{\prime}-14^{\circ} 0^{\prime} \mathrm{N}$ to $123^{\circ} 0^{\prime}-124^{\circ} 0^{\prime} \mathrm{E}$ representing about 317,103 hectares of the land area of the mainland Bicol Region in the Philippines and embraces the provinces of Albay, Camarines Sur and Camarines Norte. The basin encompasses 40 municipalities and 3 component cities situated wholly or partially within the river system and categorically divided into eight sub-basins namely, Libmanan-Pulantuna, Ragay Hills, Thiris, Naga-Yabo, Pawili River, Waras-Lalo, Naporog, and Quinali for managerial regimes. The basin is bounded by a line of volcanic mountains in the eastern rim and sedimentary terrain on its southwestern portion. The BRB is drained by a network of rivers and lakes and principally by two major rivers: the Bicol River and Libmanan River which finally empty into the San Miguel Bay situated on the northeast. The climate in the BRB is fundamentally governed by three prevailing types of climatic variations: (i) no dry season with very pronounced rainfall from November to January; (ii) rainfall more or less evenly distributed throughout the year; and (iii) not very pronounced dry season from November to April and wet during the rest of the year, for the upper portion, the central strip, and the lower portion of the BRB, respectively.

\subsection{Participatory analysis of stakeholders'} perception. Participatory and qualitative research methods such as Participatory Rural Appraisal (PRA) and Capacity Analysis, Focus Group Discussions (FGD) with the multisectoral members of the community, key informant's interview (KII) and participant observation were employed in the study. To analyze and gain the perception of the stakeholders towards vulnerability, the vulnerability matrix as qualitative tool was employed, briefly, major climate hazards and livelihood resources were identified and listed in a matrix by the respondents. In this matrix, the major hazards and most impacted livelihood resources were prioritized (Gentle \& Maraseni, 2012). Scoring for the hazards against the livelihood resources was carried out based on a Likert scale indicating the severity of impacts brought about by the identified hazards, which were represented by numerical values that correspond to a certain degree of impact (i.e. significant, moderate, minimal and no impact). Accordingly, the identified respondents in this process were farmer groups and irrigators' associations, fisherfolks (lake, river, estuary and coastal/marine fishers), private enterprises, local government agriculture service providers, local disaster risk reduction and 


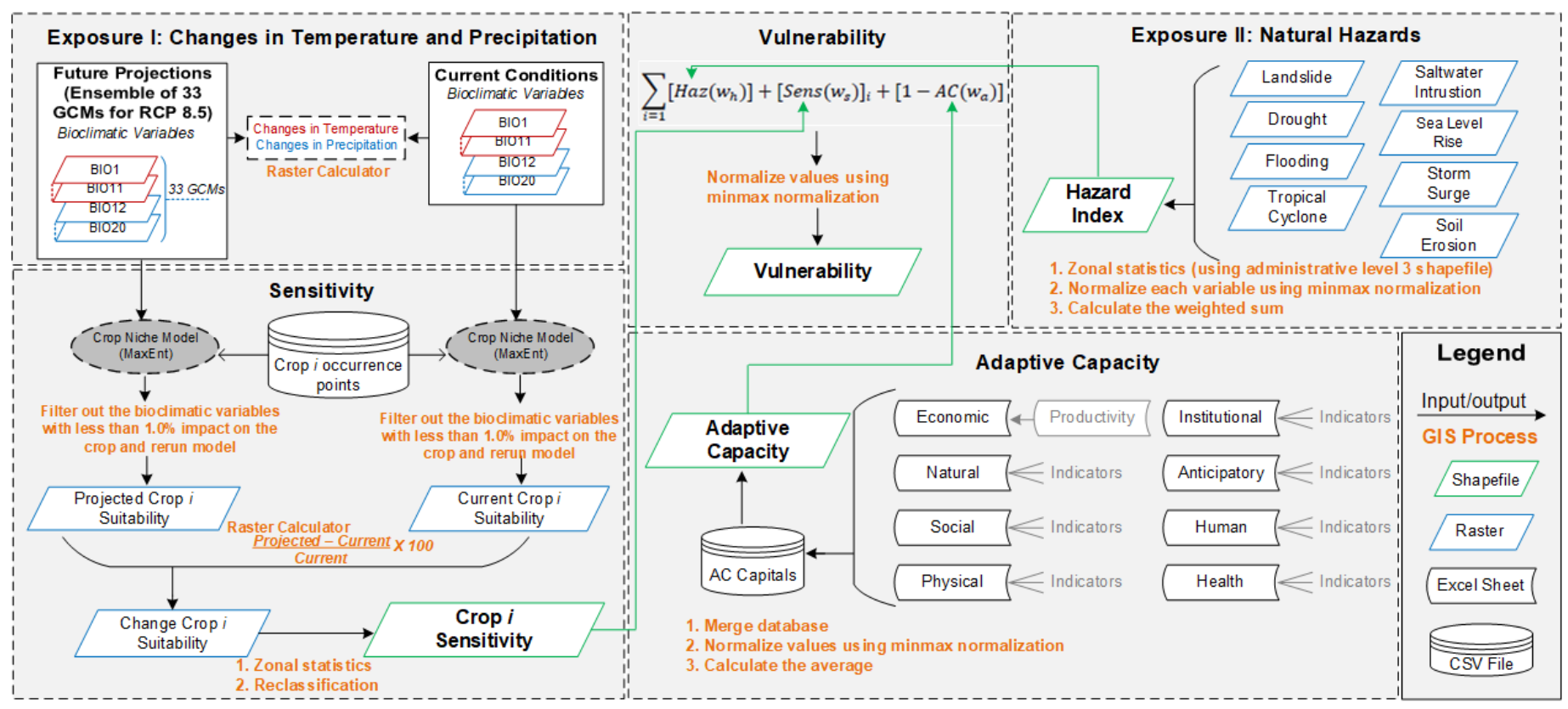

Figure 2. Climate Risk Vulnerability Assessment (CRVA) framework adapted from Parker et al. (2019) with minor modifications. The framework is classified in grey boxes according to the three main vulnerability components which were aggregated to determine the final index of vulnerability. Arrows indicate the flow of the data from input to output of the GIS processes indicated in orange. Multivariable datasets compiled in excel sheet are represented by horizontal open cylinders and raster spatial data by parallelograms except for the climatic raster where blue and red colors refer to temperature and precipitation, respectively. Green parallelograms indicate the output of the GIS process which are formatted into shapefile datasets. Finally, vertical closed cylinders are comma delimited value (CSV) file which act as a database.

management authorities including agrometeorological experts operating within the BRB.

2.3. Selection and collection of spatial data. In this section, basically, geographic information system (GIS) data which were mainly free and open source data at the finest spatial resolution possible were collected and organized by scale from global to sub-national (province to district) level (Table 1). In terms of national and subnational data collection where data distribution is protected by data privacy protocols, the figures sourcedout from various governmental agencies and instrumentalities were treated with discretion and utilized exclusively for scholarly and management purposes.

Additionally, with regards to the selection of cash crops to be utilized in the assessment, economically essential crops that are principally cultivated in the BRB were prioritized based on region-based census by the Department of Agriculture-Bicol (2017) and the Philippine
Statistics Authority (2019, 2018, 2012). The study identified and utilized five priority crops for the assessment. To assess the distribution of these crops, Species Occurrence Points (SOPs) were obtained from existing crop occurrence archives and mostly from local experts through a participatory mapping workshop. The mapping exercise was strategically designed to rapidly collect data points instead of actual field collection. Participants achieved identification of crop location based on personal knowledge, familiarity, and similarly relevant records and literatures. The resulting intermediate analog data plots were digitally exported on Google Earth and afterwards, integrated into the spatial model to enable further modelling and analyses. Validation was achieved through a series of consultation both with the experts and the immediate recipients of the generated putative maps.

2.4. Vulnerability assessment. In this section we outline the approach as to how the multiscale spatial data within the three components of vulnerability has been 
Table 1. Summary of the descriptive information in relation to the components and indicators used for the vulnerability assessment including its data sources and geospatial resolutions.

\begin{tabular}{|c|c|c|c|c|c|}
\hline Scale & $\begin{array}{c}\text { Vulnerability } \\
\text { component }\end{array}$ & Indicator & Description / Sub-indicator & Data Sources & Resolution \\
\hline \multirow[t]{3}{*}{ Global } & Sensitivity & $\begin{array}{l}\text { Current climatic } \\
\text { data }\end{array}$ & $\begin{array}{l}\text { Current temperature and } \\
\text { precipitation dating from } 1950 \text { to } \\
2000\end{array}$ & WorldClim (Fick \& Hijmans, 2017). & $\begin{array}{l}30 \text { arc seconds } \\
(\sim 1 \mathrm{~km})\end{array}$ \\
\hline & & $\begin{array}{l}\text { GCM projected } \\
\text { climatic data }\end{array}$ & $\begin{array}{l}\text { Long term projection of climate } \\
\text { (2040-2069 representing } 2050 \\
\text { decadal time period) }\end{array}$ & $\begin{array}{l}\text { Global Circulation Model (GCM) } \\
\text { (CCAFS, 2015) }\end{array}$ & $\begin{array}{l}30 \text { arc seconds } \\
(\sim 1 \mathrm{~km})\end{array}$ \\
\hline & $\begin{array}{l}\text { Natural } \\
\text { Hazards }\end{array}$ & Tropical cyclone & $\begin{array}{l}\text { Estimate of tropical cyclone } \\
\text { frequency based on Saffir- } \\
\text { Simpson Category } 5 \text { and higher } \\
\text { from year } 1990-2009\end{array}$ & ESCAP \& UNISDR (2012) & $1 \mathrm{~km}$ \\
\hline \multirow[t]{7}{*}{ National } & $\begin{array}{l}\text { Natural } \\
\text { Hazards }\end{array}$ & Flood & $\begin{array}{l}\text { Susceptibility of flood risk for } \\
\text { Philippines from the past } 10 \\
\text { years }\end{array}$ & $\begin{array}{l}\text { AMIA Multi-hazard map } \\
\text { Mines and Geo-sciences Bureau }\end{array}$ & $\begin{array}{l}1: 10,000 \text { scale } \\
\text { vector }\end{array}$ \\
\hline & & Drought & $\begin{array}{l}\text { Groundwater potential from the } \\
\text { past } 10 \text { years }\end{array}$ & $\begin{array}{l}\text { AMIA Multi-hazard map } \\
\text { National Water Resources Board } \\
\text { National Color-Coded Guide Map } \\
\text { (DA-SWCCO, 2017) }\end{array}$ & $\sim 100$ meters \\
\hline & & $\begin{array}{l}\text { Saltwater } \\
\text { intrusion }\end{array}$ & $\begin{array}{l}\text { Ground water potential for the } \\
\text { Philippines }\end{array}$ & $\begin{array}{l}\text { AMIA Multi-hazard map } \\
\text { National Water Resources Board } \\
\text { National Color-Coded Guide Map } \\
\text { (DA-SWCCO, 2017) }\end{array}$ & $\sim 100$ meters \\
\hline & & Erosion & $\begin{array}{l}\text { Soil erosion classified from low to } \\
\text { high susceptibility }\end{array}$ & $\begin{array}{l}\text { AMIA Multi-hazard map } \\
\text { Bureau of Soils and Water } \\
\text { Management }\end{array}$ & $\begin{array}{l}1: 10,000 \text { scale } \\
\text { vector }\end{array}$ \\
\hline & & Landslide & $\begin{array}{l}\text { Landslide classified from low to } \\
\text { high susceptibility }\end{array}$ & $\begin{array}{l}\text { AMIA Multi-hazard map } \\
\text { Mines and Geo-sciences Bureau }\end{array}$ & $\begin{array}{l}1: 10,000 \text { scale } \\
\text { vector }\end{array}$ \\
\hline & & Storm surge & $\begin{array}{l}\text { Total water levels, changes in } \\
\text { tidal levels, wave/surge height } \\
\text { and direction }\end{array}$ & $\begin{array}{l}\text { AMIA Multi-hazard map } \\
\text { Disaster Risk and Exposure } \\
\text { Assessment for Mitigation } \\
\text { (DREAM-DOST) }\end{array}$ & $\sim 100$ meters \\
\hline & & Sea level rise & $\begin{array}{l}\text { \# mm of sea level rise and } \\
\text { changes in tidal levels }\end{array}$ & AMIA Multi-hazard map & $\sim 100$ meters \\
\hline \multirow[t]{4}{*}{$\begin{array}{l}\text { Sub } \\
\text { national }\end{array}$} & $\begin{array}{l}\text { Adaptive } \\
\text { Capacity }\end{array}$ & Social capital & Social protection & $\begin{array}{l}\text { Department of Social Welfare and } \\
\text { Development (DSWD) }\end{array}$ & Province shapefile \\
\hline & & & $\begin{array}{l}\text { Existence of farmer unions, } \\
\text { membership in cooperatives, } \\
\text { inclusion of ethnic minorities, } \\
\text { presence of employed and } \\
\text { elected local government unit } \\
\text { staff and officials }\end{array}$ & $\begin{array}{l}\text { Municipal/City Planning and } \\
\text { Development Office (M/CPDO) } \\
\text { Municipal/City Agriculture Office } \\
\text { (M/CAO) } \\
\text { Cooperative Development } \\
\text { Authority (CDA) }\end{array}$ & District shapefile \\
\hline & & Economic capital & $\begin{array}{l}\text { Cost of living, capacity to } \\
\text { generate employment, cost of } \\
\text { doing business, presence of } \\
\text { business and professional } \\
\text { organizations }\end{array}$ & $\begin{array}{l}\text { Philippine Statistics Authority } \\
\text { (PSA) - Information Services } \\
\text { Division } \\
\text { National Wages and Productivity } \\
\text { Council (NWPC) } \\
\text { Bureau of Internal Revenue (BIR) } \\
\text { Philippine Chamber of Commerce } \\
\text { and Industry (PCCI) } \\
\text { Regional Offices of the } \\
\text { Department of Labor and } \\
\text { Employment (DOLE) }\end{array}$ & Province shapefile \\
\hline & & & $\begin{array}{l}\text { Size and growth of the local } \\
\text { economy, capacity to generate } \\
\text { employment, cost of doing } \\
\text { business, number of banks and } \\
\text { financial institutions, productivity } \\
\text { based on gross sales and } \\
\text { number of employments, } \\
\text { presence of business and } \\
\text { professional organizations, } \\
\text { access to agricultural insurance }\end{array}$ & $\begin{array}{l}\text { Municipal/City Treasurer's Office } \\
\text { (M/CTO) } \\
\text { Business Permits and Licensing } \\
\text { Office (BPLO) } \\
\text { Office of Building Official (OBO) } \\
\text { City or Municipal Engineer's Office } \\
\text { Municipal/City Agriculture Office } \\
\text { (M/CAO) } \\
\text { Cooperative Development } \\
\text { Authority (CDA) } \\
\text { Local financial institutions } \\
\text { Local electric cooperatives }\end{array}$ & District shapefile \\
\hline
\end{tabular}


Local utility service providers

Other accredited business

organizations

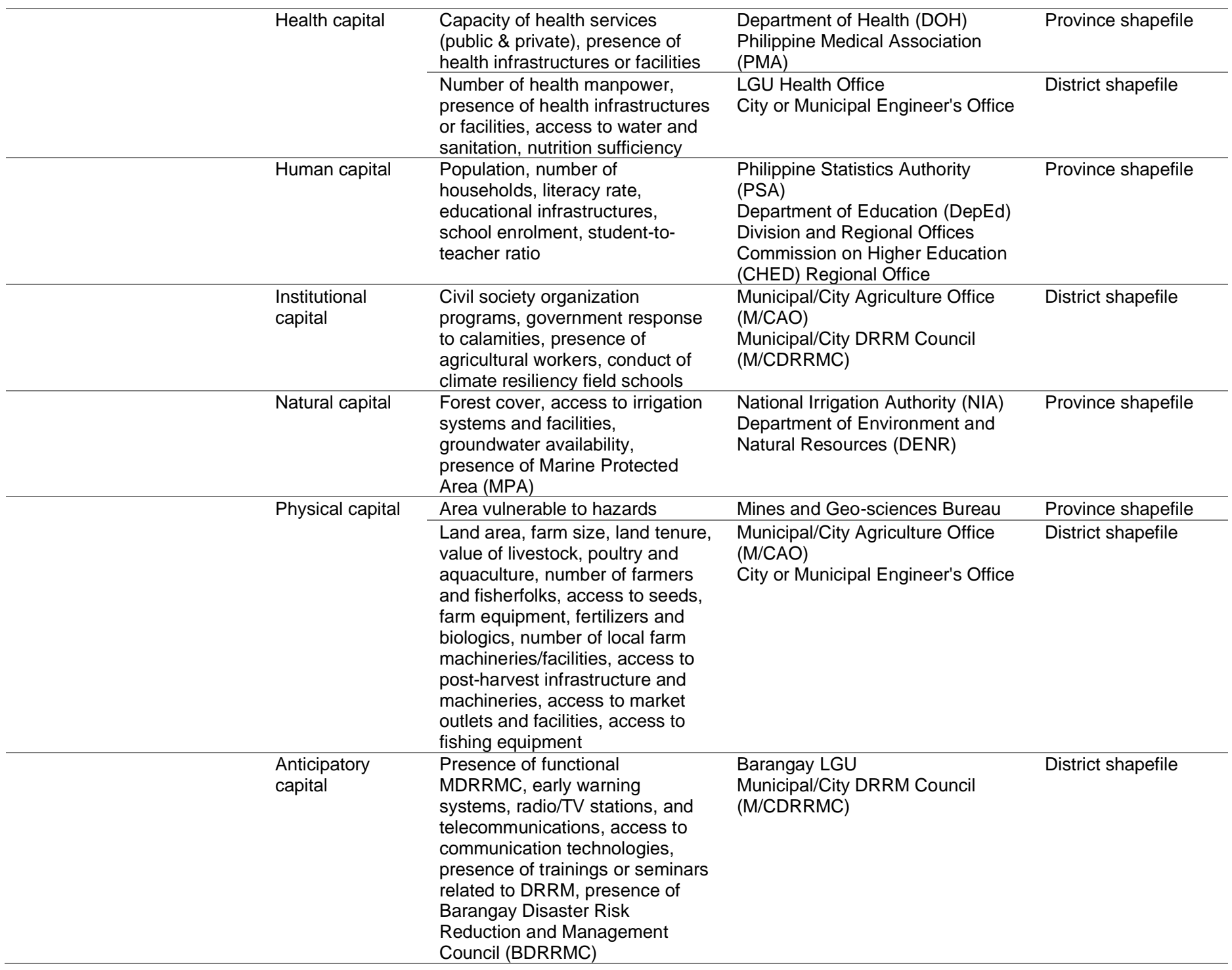

aggregated to obtain a single index of vulnerability following the framework of the International Center for Tropical Agriculture (CIAT) specifically from the works of Parker et al. (2019) with modifications. We would also like to note that the pooling of some datasets from different sources as well as the capacity building were sourced-out and sought from CIAT-Philippines through the CIATAMIA project (CIAT, 2016). Based on the CIAT framework for vulnerability assessment, we outlined the framework of the processes involved in this aggregation in Figure 2.

2.4.1. Exposure assessment. For this component, we further compartmentalized exposure into two components: first, we estimated the changes in temperature and precipitation between future projection (decade 2050) and the current or baseline conditions. And second, we factored-in several biophysical indicators which corresponds to the natural hazards exerting higher pressure to the agricultural sector and rural livelihoods such as tropical cyclone, flood, drought, saltwater intrusion, erosion, landslide, sea level rise, and storm surge.

With regards to Exposure 1, in estimating the current conditions, we used WorldClim (Hijmans et al., 2005), a global database of high spatial resolution weather and 
climate data. Using this database, spatially interpolated gridded climate data using thin-plate splines algorithm consisting of monthly total rainfall, and maximum, mean and minimum temperature, were aggregated across a target temporal range of 1970-2000 (Fick and Hijmans, 2017 ) to provide an estimate to the current scenario. For the future climate projection, we utilized the Representative Concentration Pathway (RCP) 8.5 or the high emission scenario. The RCPs form a set of greenhouse gas concentration and emissions pathways designed to support research on impacts and potential policy responses to climate change (Moss et al. 2010; van Vuuren et al. 2011). Among the four RCP, the RCP8.5 corresponds to the pathway with the highest greenhouse gas emissions and combines assumptions about high population and relatively slow income growth among others (Riahi et al., 2011). In order to model the future climate scenario, we used the mean ensemble of 33 General Circulation Models (GCMs) under RCP8.5 scenario. Afterwards, using downscaled datasets, the resulting data of the changes in precipitation and temperature were calculated by subtracting current to future climate scenario to provide an overall estimation.

In terms of the approach to Exposure 2, spatially aggregated datasets of the identified natural hazards were acquired from national sources (summarized in Table 1). By involving experts, each identified hazard was assigned different weights with respect to the three island groups in the Philippines based on probability of occurrence, impact to national economy, impact to food security of the country, impact to local household income, and finally, impact to key natural resources to sustain productivity (i.e., water quality \& quantity, biodiversity, soil fertility). For this study, we only utilized the weighted values for Luzon island since the BRB is situated solely within Luzon. Finally, to generate the hazard index, the mean values of aggregate weight for each municipality were computed. Normalization was employed to rescale all the values from 0 to 1 . Accordingly, five equal breaks were used to establish the thresholds for the following classes: $0-0.20$ (Very Low), 0.20-0.40 (Low), 0.40-0.60 (Moderate), 0.60-0.80 (High), and 0.80-1.00 (Very High).

2.4.2. Sensitivity assessment. Crop sensitivity was assessed by analyzing changes in climatic suitability of crops by the year 2050 in comparison with the current crop suitability. For this study sensitivity is described as the change in the climatic suitability of an area to grow a crop (Parker et al., 2019). To estimate this change, we subtracted the future climatic suitability from the current suitability. To model the climatic suitability of individual crops, we utilized the MaxEnt model (Elith et al., 2011) for rice, corn, cassava, taro, and tilapia since this model has been seen to perform well for crops that are often irrigated (Parker et al., 2019). Accordingly, this modelling approach is a niche-based model that assumes the distribution of observations, i.e., presence data and represents the realized niche (Heumann et al., 2011).

In order to perform necessary modelling approaches, we relied on twenty (20) statistically downscaled current and future bioclimatic variables which are derived from annual, quarterly, monthly and daily temperature and rainfall values for the purpose of producing variables that are biologically relevant. These bioclimatic variables were integrated together with the respective crop in order to produce climate suitability maps under current conditions and employed expert feedback to validate the accuracy of the map and its inputs. After which, the future data (2050), using a set of 33 statistically downscaled GCMs for the RCP8.5 emissions scenario was integrated to the niche crop model to generate 33 projected suitability outputs. From this, we computed for the average and the standard deviation to assess the degree of variability of the GCMs. We finally calculate the change (\%) between the current and projected suitability, extract the values for each administrative unit and provided classifications in terms of the sensitivity indices. An index of $-0.25--1.0$ means an increase in suitability while $0.25-1.0$ means a loss in suitability. The index equal to 0 means there is no change in suitability detected from current to projected or because there is just no crop presence.

2.4.3. Adaptive capacity assessment. In this study, adaptive capacity (AC) is understood as the ability of a system to adjust and respond to the changes in climate. Among the three components of vulnerability, it is the aspect directly correlated with resilience. For this component we compiled datasets (Table 1) for each of our respective indicators (social, economic, health, human, institutional, natural, physical, anticipatory) measured and downscaled on a sub-national level in the context of climate change effects to agriculture. The bulk of the socioeconomic information pertaining to the $\mathrm{AC}$ from each administrative unit that are relevant to its agricultural situation was surveyed and collected from sub-national (province to district) sources (e.g. 


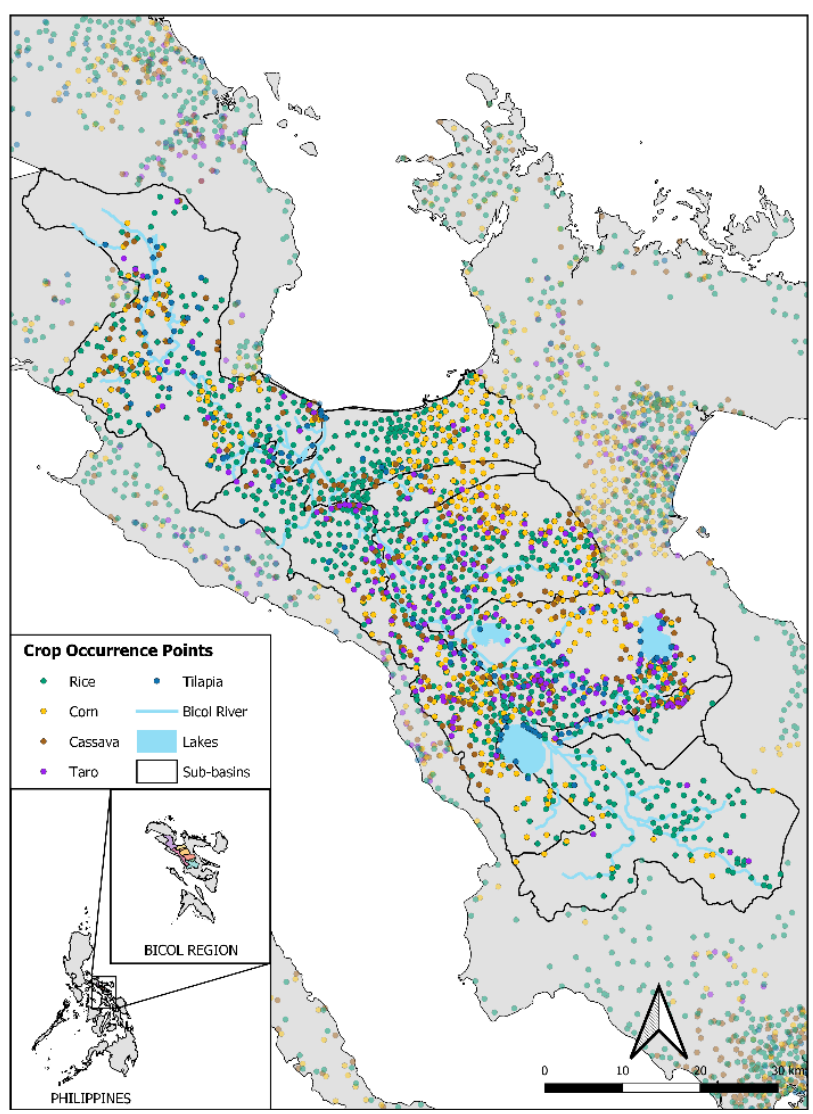

Figure 3. Species occurrence points of priority commodities that are principally cultivated within the Bicol River Basin. Each crop is given corresponding color for visualization. Crop occurrences outside the BRB border was also depicted to facilitate comparison of the vegetation cover within the area.

agriculture, planning, engineering agencies, etc.). To formulate an index, data standardization was involved to normalize the values linearly to a $0-1$ interval. This enabled us to establish thresholds categorized into five classes: $0-0.20$ (Very Low), 0.20-0.40 (Low), 0.40-0.60 (Moderate), 0.60-0.80 (High), and 0.80-1.00 (Very High).

2.4.4. Final vulnerability index assessment. In this section, we finally combined the different components of vulnerability consisting of the normalized values of exposure to natural hazards, crop sensitivity, and adaptive capacity to calculate for the overall vulnerability at the administrative boundary scale. To determine the weighted contributions to each component, a balanced weight approach (Hahn et al., 2009; Sullivan, 2002) was used in this index, assuming that each component contributes equally to the index, regardless of the number of indicators under each component. To do this, the component score was divided by the number of indicators. The weighting scheme can be adjusted to reflect the perceived importance of specific factors (Krishnamurthy et al., 2014). For example, as suggested by Eakin and Bojorquez-Tapia (2008), to determine the weightings for indicators we adopted values as a result of focus groups and expert opinion led by national experts through a national workshop to gain a consensus on the final weight to be assigned for each vulnerability component.

The calculation and analysis were subsequently carried out and mapped on QGIS 3.4 (Madeira) software. After assimilating the assigned weights to each respective component indices, the overall vulnerability was determined by aggregating the indices of the potential impact $(\mathrm{Haz}+\mathrm{Sens} i)$ and adaptive capacity (AC). For this, we employed the equation presented below.

$$
\text { Vulnerability index }=\sum_{i=1}\left[\operatorname{Haz}\left(w_{h}\right)\right]+\left[\operatorname{Sens}\left(w_{s}\right)\right]_{i}+\left[1-A C\left(w_{a}\right)\right]
$$

Where: $i=$ crop, $\mathrm{Haz}=$ hazard index, Sens $i=$ sensitivity index of the crop, and $\mathrm{AC}=$ adaptive capacity index. $w_{h}=$ weight given for hazard, $w_{s}=$ weight given for sensitivity, and $w_{a}=$ weight given for adaptive capacity.

Subsequently, expert validation was sought at various stages of the methodology (Figure 2); several stakeholders of every administrative unit participated in this consultation, consisting of agriculture service providers, DRRM and planning officers. As a heuristic tool, in certain cases that the expert recognizes areas where the model presents certain inconsistencies or inaccuracies, we subsequently re-run the model incorporating the experts' recommendations and present the restructured results, we repeat this process until the maps capture the relative spatio-temporal conditions of each administrative area. This feedback mechanism is critical in order to improve the accuracy and validity of the maps generated. After obtaining the final validated scores, we subsequently summarized the distribution of vulnerability index scores through a kernel density plot and employed statistics using $R$ software. We then categorized vulnerability according to the vulnerability score using the following conditions, Very Low-Low (Vulnerability $\leq 0.40)$, Moderate $(0.425 \leq$ Vulnerability $\leq$ 0.60 ) and High-Very High (Vulnerability $\geq 0.625$ ). 


\section{Results and Discussions}

\subsection{Perceptions of vulnerability in the BRB}

In this context, we initially conducted species occurrence survey to assess the vegetation cover in the BRB. For this, Figure 3 presents the occurrence points of priority commodities that are principally cultivated in the region. It can be distinctly noted that majority of these crops are grown within the boundaries of the basin, most prominently in its central portion where almost all crops converge along the major rivers and tributaries where supplies of freshwater are discriminately abundant. Consequently, this creates an environment of uncertainty and presents a major concern to marginalized small-scale agri-fishery farmers since largescale inundation is the most pervasive hydrological hazard that threatens the extensive low-lying Bicol Plain (DENR 2015; Mascariñas et al., 2013: Abon, et al., 2012). As part of Climate Vulnerability and Capacity Analysis (CVCA), a vulnerability matrix was prepared to gain perceptions on the vulnerability of the agriculture sector from its grassroot level. Participated by various stakeholders operating within the BRB, it was revealed that besides from frequent flooding, typhoon was perceived to contribute the most significant impact on the prioritized livelihood resources that arise from these communities. Notably, although water supply in the area should be considerably sufficient because of the wide coverage of the Bicol River, the occurrence of drought still significantly affects the area. Additionally, the occurrence of saltwater intrusion in freshwater systems in the areas located along the low-lying coastal lands was also identified to be a potent contributor in the decreased productivity of major agricultural practices since it has been documented that soil biogeochemistry can be dramatically altered as saltwater intrudes these agricultural fields (Tully et al., 2019). These problems arise considerably due to water management facilities and infrastructures that are poorly designed, misaligned, operationally underperforming or constructed disproportionately to function during such debilitating scenarios. The presence of pests and diseases as well as farm vermin were also identified to cause significant to moderate impact on major agricultural products these include pests such as the black bugs (Scotinophara spp.), stem borer larvae (Scirpophaga spp. \& Chilo spp.), armyworms
(Spodoptera spp.) and green leafhoppers (Nephotettix spp.) which also transmit the viruses that cause rice tungro disease and other various plant diseases such as mildew and anthracnose caused by fungi and bacterial blights. Other farm pests were also reported to cause major crop damages such as golden apple snails (Pomacea canaliculata) and other larger wild animals such as farm rats (Rattus spp.) and rice-eating birds (Lonchura spp. \& Passer montanus). Accordingly, the most vulnerable livelihood determined by the stakeholders revealed to be rice cultivation followed by the high-value crops and then the livestock and poultry based on the composite data (see Fig. 4).

\subsection{Main context of vulnerability}

Given the rate and breadth to which climate change is already exerting increased pressure upon many vulnerable communities (Gentle \& Maraseni, 2012; Laukkonen, et al., 2009), and the relatively finite resources available to various stakeholders to mitigate its impacts (Buchner, et al., 2017), it is of paramount importance that interventions are strategically planned and implemented (Weis et al., 2016). Over the past decade, there is an increasing body of literature that focused on evaluating the vulnerability of various sectors to climate change, including agriculture (Jurgilevich, et al., 2017: Mallari, 2016: Acheampong, et al., 2014: Wu, et al., 2011: Ford, et al., 2010). Characterizing vulnerability is central to identifying adaptation needs and informing adaptation policy development (Ford, et al., 2010). It is integral, therefore, in all vulnerability assessment undertakings to keenly understand what constitutes vulnerability; a number of studies (Vos, et al., 2016: Baca, et al., 2014: Füssel, 2010: Deressa, et al., 2008) have adopted what seems to be the most authoritative (Hinkel, 2011) definition of vulnerability developed by the Intergovernmental Panel on Climate Change (IPCC) (IPCC, 2001: McCarthy, et al., 2001) which can be defined as "the extent to which a natural or social system is susceptible to sustaining damage from climate change impacts, and is a function of the character, magnitude, and rate of climate variation to which a system is exposed, its sensitivity, and its adaptive capacity" (McCarthy, et al., 2001). The susceptibility of agriculture and livelihoods to climate change therefore can be presented as the aggregation of these composite components (Fritzsche, et al., 2014). 

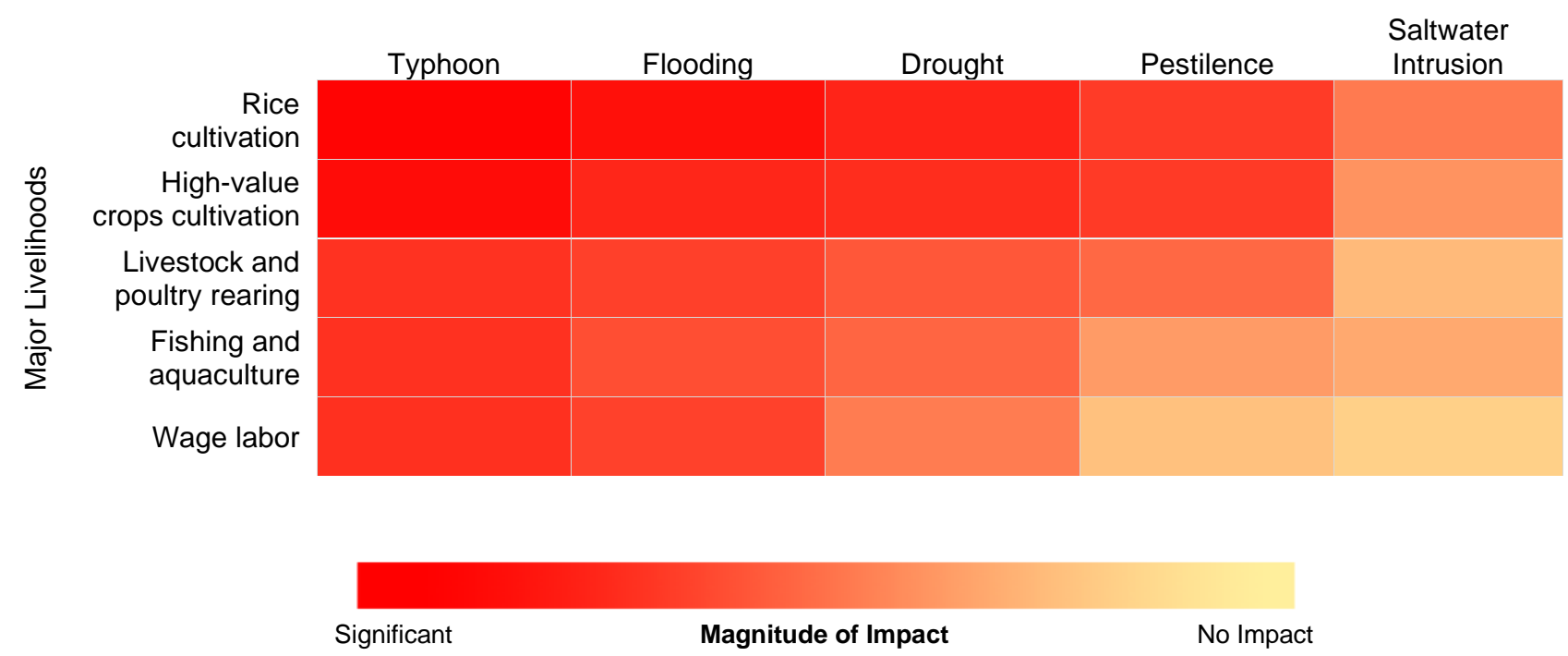

Figure 4. Vulnerability matrix representing stakeholders' $(N=330)$ perception towards vulnerability of the agriculture sector in terms of rural agri-fishery livelihoods versus the major hazards that is widely experienced in the Bicol River Basin. Results are expressed across a color gradient that represents the perceived magnitude of impact from crimson (significant), light red (moderate), orange (minimal) to light yellow (no impact) following the Likert scale.
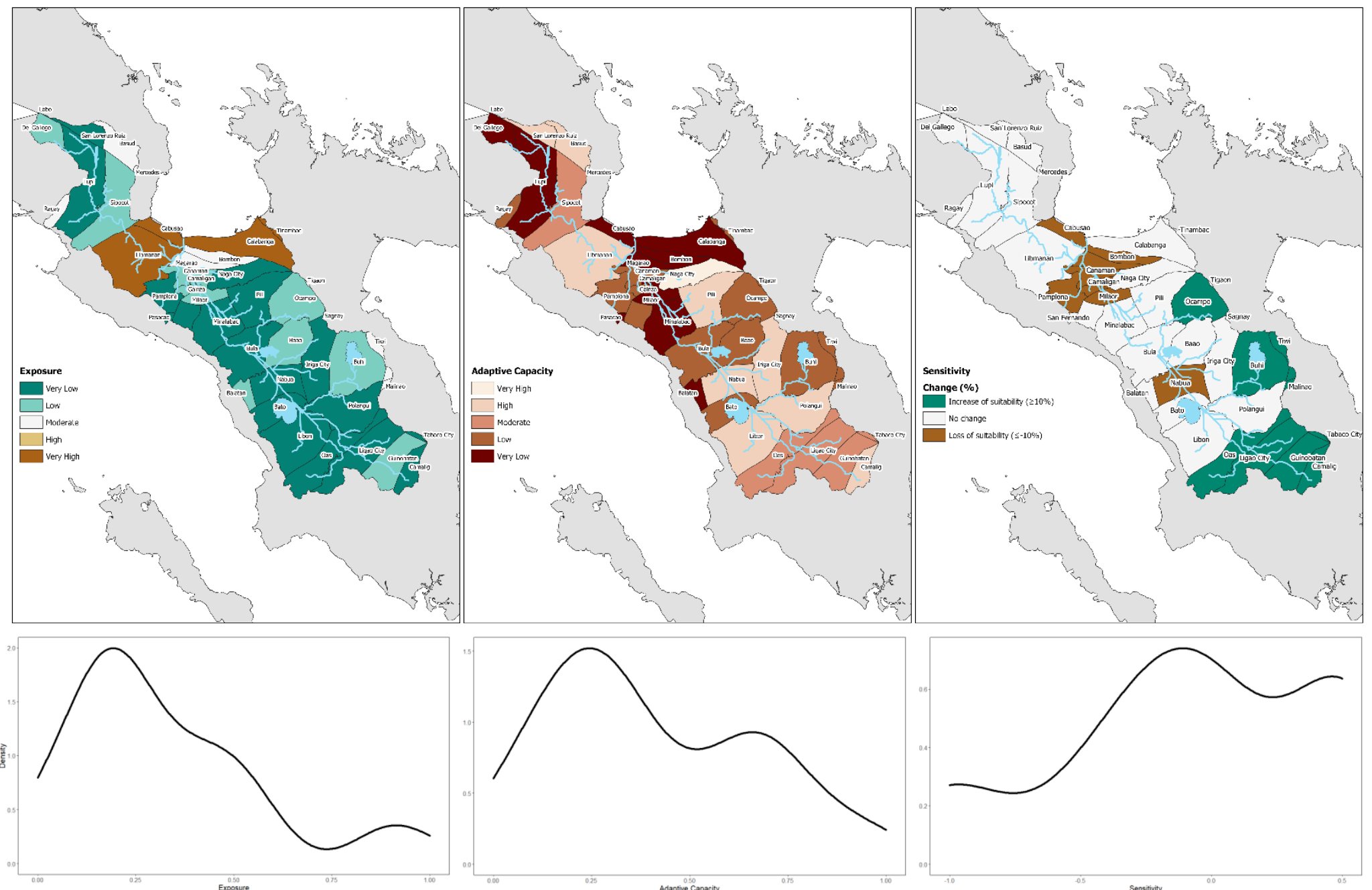

Figure 6. Individual vulnerability component maps and kernel density plots showing the distribution of the vulnerability components: Exposure (left), Adaptive Capacity (middle), and Sensitivity (right). 
Meanwhile, it is crucial to understand that vulnerability is not a quantifiable phenomenon, it is instead a dynamic state which is the result of various interacting variables (Fritzsche, et al., 2014). As it cannot be measured or observed directly (Sherbinin, et al., 2017; Hamouda, et al., 2009), a number of indicators which are presumed to affect vulnerability are aggregated or combined to provide an indication, or an index of vulnerability. Likewise, it is a relative scale which shows the spatial distribution of vulnerability within a specific location of analysis, which in our case is a water system. The aforementioned components or indicators are commonly used variables of agricultural vulnerability (Fritzsche, et al., 2014). Briefly, these indicators capture a region's, in our case, the provinces' high biophysical and climate risks (Exposure), resilience of the crop production systems (Sensitivity) and societal capacity to respond (Adaptive Capacity).

\subsection{Vulnerability scenario in the BRB}

The following section summarizes the results of the vulnerability indexing exercise. For comparison, it is important to note that index values should be interpreted as relative, rather than indicative, within the context of the analysis. The putative maps can be interpreted as a baseline showing the vulnerability of administrative regions, relative to each other, based on current climate and socioeconomic profiles.

The results suggest that there are geographical patterns of climate-related vulnerability within the BRB (Fig. 5). Notably, Thiris sub-basin (composed mainly of the towns of Calabanga, Bombon, Magarao, and Canaman) is significantly vulnerable to the impacts of climate change along with other parts of Ragay Hills (Minalabac, Milaor, Balatan and parts of Pasacao), Waras-Lalo (Baao) and the Libmanan-Pulantuna (Del Gallego, Cabusao, and Lupi) sub-basins, due to loss in the climatic suitability, the presence of multiple natural hazards (tropical cyclone, flooding, drought and some expected saltwater intrusions) and also the relatively low adaptive capacity in these areas. On the contrary, the Quinali sub-basin (composed of the towns of Camalig, Guinobatan, Libon, Ligao City, Oas, and Polangui) wholly has the capacity to resist climate change relative to cultivating these crops together with some parts of Waras-Lalo (Iriga City and Nabua), Pawili River (Pili) and the northeastern portion of the Libmanan-Pulantuna (San Lorenzo Ruiz, Basud,
Sipocot, and parts of Mercedes). Overall percentages show that $42 \%$ of the towns in the BRB are relatively characterized by high to very high vulnerability, whereas, $37 \%$ are characterized by low to very low vulnerability. Accordingly, the remaining $21 \%$ of the towns are relatively characterized moderate. This suggests three important observations which may need further empirical analysis. First, communities within the BRB greatly rely on agri-fishery based enterprises (Fig. 4) for food security that in essence, heavily depends on the climate, therefore, food productivity and changes in the climate is closely interlinked. Second, climate change has the capacity to potentially disrupt the agrifood value chains (Lim-Camacho, et al., 2017) to which food security heavily depends. And third, climate change tends to impact communities disproportionately which further exacerbates poverty across the BRB. These vastly illustrates how the consequences of vulnerability will reverberate across highly vulnerable areas in the BRB if not addressed urgently and holistically.

To further analyze the trend of vulnerability across the $\mathrm{BRB}$, we summarized the distribution of vulnerability index scores through a kernel density plot (Fig. 5). Data distribution for vulnerability yielded a bimodal distribution such that the average vulnerability category is moderate (0.492) with the main peak at around 1.5 and a lower peak around 1.1. However, the distribution suggests a segregation of two distinct local maxima consisting of vulnerability scores that relatively fall under distinct ranges of high $(>0.625)$ and low $(<0.40)$ vulnerability categories, respectively. The dimensional nature of the data arises as a result of how climate change impacts every single administrative unit disproportionately, that is, administrative units or towns with increased economic growth have the capacity to cope with the effects of climate pressures thereby resulting to a relatively lower climate vulnerability, these gradually adds up to form the global maximum (main peak). Whereas, towns that are economically disadvantaged have relatively high vulnerability, therefore, clusters to form the local maximum (lower peak). The graph, therefore, implies that although there exist a considerable number of towns that are already vulnerable to the impacts of climate-related risks, majority of the towns have relatively high coping chances. 

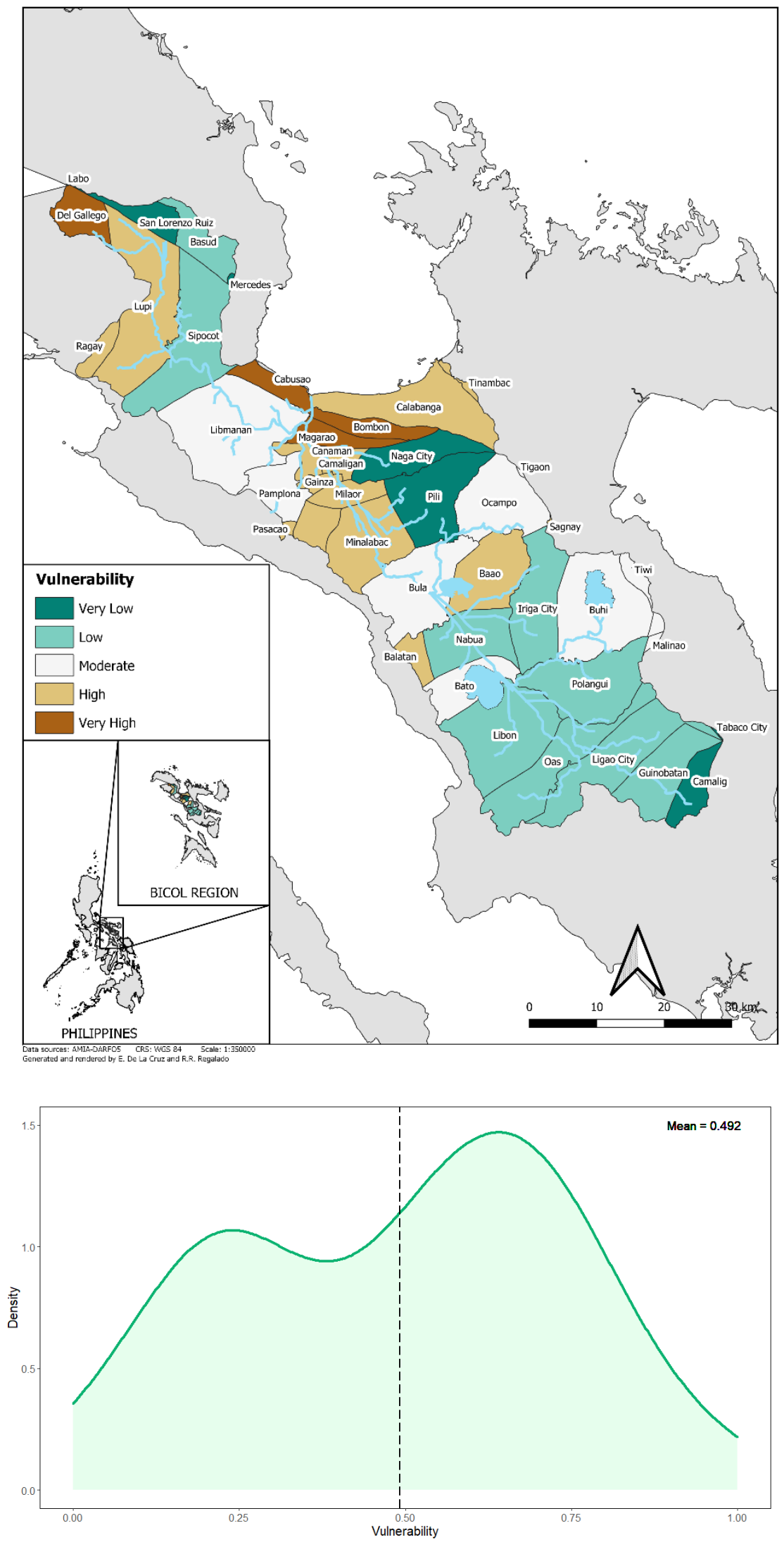

Figure 5. Climate vulnerability scenario (2050) under a high emission scenario (RCP 8.5) of the Bicol River Basin, calculated as a function of exposure to natural hazards, sensitivity of selected crops to climate change and adaptive capacity of the population. Kernel density plot shows the summarized distribution of vulnerability index scores across administrative units. 
The geographical and density distributions of the specific indicators shown in Fig. 6 further reveal each indicators contribution to the overall vulnerability of the BRB. First, hazard exposure for the BRB was observed to be highest in some parts of the Thiris and southern portion of the Libmanan-Pulantuna sub-basins characterizing about $9 \%$ of the overall exposure of the typhoon track found within the latitude range $14^{\circ} \mathrm{N}-$ $16^{\circ} \mathrm{N}$ where most tropical cyclones typically landfall (Takagi \& Esteban, 2016: Meigh \& Bartlett, 2010) which encourages further risks brought about by storm surges and sea level rise due to their immediate proximity to the seaboards, which in turn bring further flooding and occasional soil erosion in these areas. Moreover, adaptive capacity $(A C)$ tends to be lowest in some portions of the Libmanan-Pulantuna and Ragay Hills sub-basins and very notable entirely in the Thiris subbasin, additionally, some towns within the sub-basins of Pawili River, Waras-Lalo and remaining parts of Ragay Hills are also characterized by low AC comprising about $58 \%$ of the overall adaptive capacity of the towns in the BRB. Finally, in terms of sensitivity, the averaged values of the five (5) major crops considered in this study suggests a decline in suitability $(21 \%)$ in the central portion of the BRB along the borders of Libmanan-Pulantuna, Thiris and Ragay Hills including a town in the Waras-Lalo sub-basin. Nevertheless, increased suitability $(21 \%)$ is observed in the southern portion of the Quinali and parts of the Waras-Lalo and Pawili River sub-basins, remaining towns was observed to have no change in suitability (58\%). The challenge for policy now will be on how to mobilize contingency measures, initiate responsibility, and stimulate conversation amongst concerned stakeholders and policy makers in terms of investing in climate change adaptation strategies and heightened risk managements in the areas characterized by high vulnerability.

\section{Limitations}

Notwithstanding the seamless projection generated by the model, several limitations and caveats apply to our study. First, we acknowledged that the climate model outputs contain uncertainties due to factors such as lack of capability to represent the complexity of Earth's climate system, multiple emission scenarios, and unaccounted ecological and anthropogenic processes. However, despite such uncertainties, models remain a useful tool to forecast the impact of the future climate (Upgupta, et al., 2015). For future studies, we recommend the use of multiple modelling tools, since it can reduce the level of uncertainty (Alam and Starr, 2013). Second, although our model allows for identifying the sensitivity of the area, bioclimatic factors and species occurrence were only used for the basis of the future projection, supplemental indicators like elevation, soil texture, and soil moisture were disregarded since most of the commodities grown in the BRB are strictly distributed throughout the Bicol Plain (Fig. 3) where pedological properties (Carating, et al., 2014) remain relatively uniform. Moreover, there still exist conceptual confusions on how vulnerability should be formally defined (Wolf, et al., 2013: Hinkel, 2011). The plurality of existing frameworks and possible interpretations even the selection of indicating variables are still contestable from a scientific point of view. Hinkel (2011) provided a framework where he decomposed the IPCC definition on the basis of the definitions of the defining concepts given in glossary of the Third Assessment Report (McCarthy et al., 2001) and presented concepts that are left undefined on a scientific purview. For simplicity, we kept the wellestablished definition of the IPCC to provide context to our readers suggesting that the definition to be conventional. Further researches should be conducted to explicitly provide standardized terminologies to address these gaps.

\section{Recommendations}

As we find ourselves today at the crossroads of multiple upheavals: the recent COVID-19 global emergency and a major economic downturn, the threat of the climate crisis looms larger than ever. With the growing challenges confronted by the local agri-fishery sector, well-placed policy and institutional landscape strategies would significantly contribute in mitigating the consequences of the volatilities brought about by the current climate scenario. Additionally, tailor-made adaptation policies should be conceptualized since agricultural practices exist in a unique set of conditions relative to its ecological importance, current biophysical status, the past history of management, stakeholder dynamics, local customs and traditions, local community-based institutions, and local economy (Upgupta, et al., 2015). In a broader sense, studying the multi-faceted aspects of climate change falls not only at 
the forefront of the academia instead it transcends into a collaborative political and social duty. Information generated by vulnerability assessments is meant to cater further policy purposes such as updating of local climate change action plans (LCCAP) and advocating for common-sense climate solutions like clean energy promotion, climate-resilient agriculture practices, and regenerative agriculture among others. Assessing vulnerability thus has moved from being an academic exercise to being a political necessity (Hinkel, 2011).

Our findings can therefore be utilized especially by local government units (LGUs) to attract bilateral and multilateral support from various local and international stakeholders, prioritize and inform climate adaptation efforts that will minimize its impacts, for example, by bolstering the adaptive capacity of vulnerable areas, that is, by improving education, income distribution, institutions and health care, pre- and post-disaster responses and increased accessibility to early warning systems as these may help offset projected increases in vulnerability. Likewise, strategies to promote resilience of ecosystems should also be given significant attention since a wide range of ecosystem services provided by the BRB are threatened by anthropogenic activities such as timber poaching, mangrove conversion, and over fishing among others. These strategies should include but not limited to protection of existing natural forests, rehabilitation of degraded forestlands and protected areas, management of mangroves, wetlands and coastal resources and management of river easements, including resettlement planning and implementation. It is also essential to upgrade water management facilities and retrofit existing infrastructures since it has been found out that saltwater intrusion and largescale flooding continues to persist in the area. Moreover, gradual crop shifting is also fundamental in order to maintain the comparative advantage of the farmers.

\section{Conclusion}

Our results highlighted specific regions of the Bicol River Basin where projected climate vulnerability will be expected to be widespread and robust, including the vulnerability perceptions of the local communities that are disproportionately influenced by the climate crisis. These findings have large implications on how agriculture will transform in the future into a climate smart endeavor. We find that the model currently projects that majority of the towns in the north and central portions of the BRB will largely experience decline in agricultural productivity, if, stringent adaptation and mitigation measures will not be strategized and established henceforth. For this, it is vital that location-specific needs-based legislations should be established that shall help prioritize, protect, support, and incentivize the local agri-fishery sector most importantly its farmers - as they remain to be one of the country's backbone and pride of the working class.

\section{Acknowledgements}

This work was financially supported by the Department of Agriculture Regional Field Office 5 under Rice Program through the initiatives and support of its former regional executive director Dr. Elena B. De Los Santos. The authors acknowledge Director Rodel P. Tornilla and the Bicol AMIA team headed by Mr. Lorenzo L. Alvina for their support and technical assistance. The same acknowledgement is given to Dr. Raul G. Bradecina for his insightful comments and suggestions. The authors also honor the contribution of the people in the research sites for their cooperation, support, and invaluable feedbacks during the project implementation.

\section{Competing interests}

The authors declare no competing interests.

\section{References}

Abon, C. C., David, C. P. C., \& Tabios, G. Q. (2012). Community-based monitoring for flood early warning system. Disaster Prevention and Management: An International Journal.

Acheampong, E. N., Ozor, N., \& Owusu, E. S. (2014). Vulnerability assessment of Northern Ghana to climate variability. Climatic change, 126(1-2), 31-44.

Alam, S. A., \& Starr, M. (2013). Impacts of climate change on savannah woodland biomass carbon density and water-use: a modelling study of the Sudanese gum belt region. Mitigation and Adaptation Strategies for Global Change, 18(7), 979-999. 
Alberto, M. C. R., Hirano, T., Miyata, A., Wassmann, R., Kumar, A., Padre, A., \& Amante, M. (2012). Influence of climate variability on seasonal and interannual variations of ecosystem $\mathrm{CO} 2$ exchange in flooded and non-flooded rice fields in the Philippines. Field Crops Research, 134, 80-94.

Baca, M., Läderach, P., Haggar, J., Schroth, G., \& Ovalle, O. (2014). An integrated framework for assessing vulnerability to climate change and developing adaptation strategies for coffee growing families in Mesoamerica. PloS one, 9(2), e88463.

Buchner BK, Oliver P, Wang X, Carswell C, Meattle C, Mazza F. Global Landscape of Climate Finance 2017 [Internet]. Climate Policy Initiative; 2017. Available: https://climatepolicyinitiative.org/wpcontent/uploads/2017/10/2017-GlobalLandscape-of-Climate-Finance.pdf

Carating, R. B., Galanta, R. G., \& Bacatio, C. D. (2014). The soils of the lowlands. In The Soils of the Philippines (pp. 51-106). Springer, Dordrecht.

International Center for Tropical Agriculture (CIAT). (2016). Climate-Risk Vulnerability Assessment (CRVA) to support regional targeting and planning for the Adaptation and Mitigation Initiative in Agriculture (AMIA) [Internet]. Available: $\quad$ https://ciat.cgiar.org/ciatprojects/climate-risk-vulnerability-assessmentcrva-to-support-regional-targeting-andplanning-for-the-adaptation-and-mitigationinitiative-in-agriculture-amia/

Climate Change and Food Security (CCAFS). (2015). GCM Downscaled Data Portal [Internet]. Available: http://www.ccafs-climate.org/data spatial downscaling

Department of Environment and Natural Resources (DENR). (2015). Formulation of an Integrated Bicol River Basin Management and Development Master Plan Executive Summary Vol. 1. Naga City: Department of Environment and Natural Resources.

Department of Agriculture. (2017). 2017 Annual Report. Pili, Camarines Sur: Department of Agriculture
Regional Field Office 5 Planning, Monitoring \& Evaluation Division. Retrieved from http://bicol.da.gov.ph/rfo5newweb/wpcontent/uploads/2019/02/DA-RFO-5-AnnualReport-2017-web.pdf

Department of Agriculture Systems-Wide Climate Change Office (DA-SWCCO). (2017). How to use the National Color-Coded Agricultural Guide (NACCAG) Map. Retrieved from http://swcco.da.gov.ph/index.php/2017/08/02/h ow-to-use-the-national-color-codedagricultural-guide-naccag-map/

Deressa, T., Hassan, R. M., \& Ringler, C. (2008). Measuring Ethiopian farmers' vulnerability to climate change across regional states. Intl Food Policy Res Inst.

Dilshad, T., Mallick, D., Udas, P. B., Goodrich, C. G., Prakash, A., Gorti, G., ... \& Habib, N. (2019). Growing social vulnerability in the river basins: Evidence from the Hindu Kush Himalaya $(\mathrm{HKH})$ Region. Environmental Development, 31, 1933.

Doroteo, H. J. (2015). Philippines: Disaster risk profile and Disaster Risk Reduction (DDR) framework: Natural calamities. University of Oviedo, Asturias, Spain, 1-46.

Eakin, H., \& Bojórquez-Tapia, L. A. (2008). Insights into the composition of household vulnerability from multicriteria decision analysis. Global Environmental Change, 18(1), 112-127.

Elith, J., Phillips, S. J., Hastie, T., Dudík, M., Chee, Y. E., \& Yates, C. J. (2011). A statistical explanation of MaxEnt for ecologists. Diversity and distributions, 17(1), 43-57.

ESCAP \& UNISDR. (2012). Reducing vulnerability and exposure to disasters: the Asia-Pacific Disaster Report 2012. Economic and Social Commission for Asia and the Pacific and the United Nations Office for Disaster Risk Reduction, Regional Office, AP, Thailand

FAO, 2000. In: FAO (Ed.), The Ecocrop Database. Rome, Italy. 
Fick, S. E., \& Hijmans, R. J. (2017). WorldClim 2: new $1-\mathrm{km}$ spatial resolution climate surfaces for global land areas. International Journal of Climatology, 37(12), 4302-4315.

Ford, J. D., Keskitalo, E. C. H., Smith, T., Pearce, T., Berrang-Ford, L., Duerden, F., \& Smit, B. (2010). Case study and analogue methodologies in climate change vulnerability research. Wiley Interdisciplinary Reviews: Climate Change, 1(3), 374-392.

Fritzsche K, Schneiderbauer S, Bubeck $\mathrm{P}$, Kienberger S, Buth M, Zebisch M, et al. (2014). The Vulnerability Source Book. Concept and guidelines for standardised vulnerability assessments. Deutsche Gesellschaft für Internationale Zusammenarbeit (GIZ) $\mathrm{GmbH}$. Available: http://www. adaptationcommunity.net/?wpfb_dl=203

Füssel, H. M. (2010). Review and quantitative analysis of indices of climate change exposure, adaptive capacity, sensitivity, and impacts. Washington, DC: World Bank.

Gentle, P., \& Maraseni, T. N. (2012). Climate change, poverty and livelihoods: adaptation practices by rural mountain communities in Nepal. Environmental science \& policy, 21, 2434.

Gohari, A., Eslamian, S., Abedi-Koupaei, J., Bavani, A. M., Wang, D., \& Madani, K. (2013). Climate change impacts on crop production in Iran's Zayandeh-Rud River Basin. Science of the Total Environment, 442, 405-419.

Hahn, M. B., Riederer, A. M., \& Foster, S. O. (2009). The Livelihood Vulnerability Index: A pragmatic approach to assessing risks from climate variability and change-A case study in Mozambique. Global environmental change, 19(1), 74-88.

Hamouda, M. A., El-Din, M. M. N., \& Moursy, F. I. (2009). Vulnerability assessment of water resources systems in the Eastern Nile Basin. Water resources management, 23(13), 2697-2725.
Herrin, A. N. (2019). Fertility and family planning behavior in the Bicol river basin. Transactions of the National Academy of Science and Technology/National Academy of Science and Technology.(Bicutan, Taguig: NAST).

Heumann, B. W., Walsh, S. J., \& McDaniel, P. M. (2011). Assessing the application of a geographic presence-only model for land suitability informatics, 6(5), 257-269.

Hijmans, R. J., Cameron, S. E., Parra, J. L., Jones, P. G., \& Jarvis, A. (2005). Very high-resolution interpolated climate surfaces for global land areas. International Journal of Climatology: A Journal of the Royal Meteorological Society, 25(15), 1965-1978.

Hijmans, R.J., Guarino, L., Cruz, M., Rojas, E., 2001. Computer tools for spatial analysis of plant genetic resources data. 1. DIVA-GIS. Plant Genetic Resources Newsletter 127, 15-19.

Hinkel, J. (2011). "Indicators of vulnerability and adaptive capacity": towards a clarification of the science-policy interface. Global environmental change, 21(1), 198-208.

IPCC. (2001). Climate Change 2001: Synthesis Report. A Contribution of Working Groups I, II, and III to the Third Assessment Report of the Intergovernmental Panel on Climate Change [Watson, R.T. and the Core Writing Team (eds.)]. Cambridge University Press, Cambridge, United Kingdom, and New York, NY, USA.

Johnson, F. A., \& Hutton, C. W. (2014). Dependence on agriculture and ecosystem services for livelihood in Northeast India and Bhutan: vulnerability to climate change in the Tropical River Basins of the Upper Brahmaputra. Climatic change, 127(1), 107121.

Jurgilevich, A., Räsänen, A., Groundstroem, F., \& Juhola, S. (2017). A systematic review of dynamics in climate risk and vulnerability assessments. Environmental Research Letters, 12(1), 013002. 
Krishnamurthy, P. K., Lewis, K., \& Choularton, R. J. (2014). A methodological framework for rapidly assessing the impacts of climate risk on national-level food security through a vulnerability index. Global Environmental Change, 25, 121-132.

Laukkonen, J., Blanco, P. K., Lenhart, J., Keiner, M., Cavric, B., \& Kinuthia-Njenga, C. (2009). Combining climate change adaptation and mitigation measures at the local level. Habitat International, 33(3), 287-292.

Lim-Camacho, L., Ariyawardana, A., Lewis, G. K., Crimp, S. J., Somogyi, S., Ridoutt, B., \& Howden, S. M. (2017). Climate adaptation of food value chains: the implications of varying consumer acceptance. Regional environmental change, 17(1), 93-103.

Mallari, A. E. C. (2016). Climate change vulnerability assessment in the agriculture sector: Typhoon Santi experience. Procedia-Social and Behavioral Sciences, 216(216), 440-451.

Marshall, N. A., Marshall, P. A., Tamelander, J., Obura, D., Malleret-King, D., \& Cinner, J. E. (2009). A framework for social adaptation to climate change. IUCN-The International Union for the Conservation of Nature. Gland, Switzerland.

Mascariñas, A. M., Baas, S., Köksalan, N., Amano, L. O., Nieves, P. M., Binoya, C. S., ... \& Torrente, E. C. (2013). Mainstreaming disaster risk reduction into agriculture: a case study from Bicol Region, Philippines. Environment and Natural Resources Management Series, Monitoring and Assessment-Food and Agriculture Organization of the United Nations, (20).

McCarthy, J.J., Canziani, O.F., Leary, N.A., Dokken, D.J., White, K.S. (Eds.). (2001). Climate Change 2001: Impacts, Adaptation, and Vulnerability: Contribution of Working Group II to the Third Assessment Report of the Intergovernmental Panel on Climate Change. Cambridge University Press, Cambridge. p. 995.
Meigh, J. D., \& Bartlett, J. M. (2010). Integrated river basin management in Southeast Asia. Journal of Flood Risk Management, 3(3), 201-209.

Moss, R. H., Edmonds, J. A., Hibbard, K. A., Manning, M. R., Rose, S. K., Van Vuuren, D. P., ... \& Meehl, G. A. (2010). The next generation of scenarios for climate change research and assessment. Nature, 463(7282), 747-756.

Parker, L., Bourgoin, C., Martinez-Valle, A., \& Läderach, P. (2019). Vulnerability of the agricultural sector to climate change: The development of a pan-tropical Climate Risk Vulnerability Assessment to inform subnational decision making. PloS one, 14(3), e0213641.

Peñalba, L. M., Elazegui, D. D., Pulhin, J. M., \& Cruz, R. V. O. (2012). Social and institutional dimensions of climate change adaptation. International Journal of Climate Change Strategies and Management.

Philippine Statistics Authority. (2019). Crops Statistics of the Philippines. Quezon City: Crops Statistics Division. Retrieved from https://psa.gov.ph/sites/default/files/Crops\%20 Statistics\%20of\%20the\%20 Philippines\%202014-2018.pdf

Philippine Statistics Authority. (2018). JanuaryDecember 2017 Fisheries Situation Report. Quezon City: Philippine Statistics Authority Fisheries Statistics Division. Retrieved from https://psa.gov.ph/sites/default/files/FSR2017 $\underline{0 . p d f}$

Philippine Statistics Authority. (2012). Major Crops Statistics of the Philippines. $10^{\text {th }}$ Ed. Quezon City: Crops Statistics Division. Retrieved from https://psa.gov.ph/sites/default/files/MajorCrop s10-14.pdf

Riahi, K., Rao, S., Krey, V., Cho, C., Chirkov, V., Fischer, G., ... \& Rafaj, P. (2011). RCP 8.5-A scenario of comparatively high greenhouse gas emissions. Climatic Change, 109(1-2), 33.

Rola, A.C., Tornilla, R.P., Sambajon, S., Ravago, E., Penaserado, V., Payonga, A., . . Agua, A. (2018). Water Security Under Climate Risks: A 
Philippine Climate Change Adaptation Strategy for the Agriculture Sector (Bicol Agri-Water Project) - Final Report 2012-2017. University of the Philippines Los Baños, Laguna. Retrieved from https://www.climatelinks.org/resources /water-security-under-climate-risks-philippineclimate-change-adaptation-strategy

Sherbinin, A. D., Apotsos, A., \& Chevrier, J. (2017). Mapping the future: Policy applications of climate vulnerability mapping in West Africa. The Geographical Journal, 183(4), 414425.

Stuecker MF, Tigchelaar M, Kantar MB. (2018). Climate variability impacts on rice production in the Philippines. PLoS ONE 13(8): e0201426.

Sullivan, C. (2002). Calculating a water poverty index. World development, 30(7), 1195-1210.

Takagi, H., \& Esteban, M. (2016). Statistics of tropical cyclone landfalls in the Philippines: unusual characteristics of 2013 Typhoon Haiyan. Natural Hazards, 80(1), 211-222.

Tully, K. L., Weissman, D., Wyner, W. J., Miller, J., \& Jordan, T. (2019). Soils in transition: saltwater intrusion alters soil chemistry in agricultural fields. Biogeochemistry, 142(3), 339-356.

Usamah, M. B., \& Alkema, D. (2006). Simulating scenario floods for hazard assessment on the lower Bicol floodplain, the Philippines. In Advances in Geosciences: Volume 4: Hydrological Science (HS), 69-74.
Van Vuuren, D. P., Edmonds, J., Kainuma, M., Riahi, K., Thomson, A., Hibbard, K., ... \& Masui, T. (2011). The representative concentration pathways: an overview. Climatic change, 109 (1-2), 5.

Vos R, Cattaneo A, Stamoulis K, Semedo MH, Salazar RC, Frick M, et al., editors. (2016). The State of Food and Agriculture. Climate change, agriculture and food security. Rome: Food and Agriculture Organization of the United Nations. Office for Corporate Communication.

Weis SWM, Agostini VN, Roth LM, Gilmer B, Schill SR, Knowles JE, et al. Assessing vulnerability: an integrated approach for mapping adaptive capacity, sensitivity, and exposure. Climatic Change. 2016; 136: 615-629.

Wolf, S., Hinkel, J., Hallier, M., Bisaro, A., Lincke, D., lonescu, C., \& Klein, R. J. (2013). Clarifying vulnerability definitions and assessments using formalisation. International Journal of Climate Change Strategies and Management.

World Bank. (2013). Building resilience: Integrating climate and disaster risk into development. Lessons from world bank group experience. Washington, DC: Author.

Wu, J., He, B., Lü, A., Zhou, L., Liu, M., \& Zhao, L. (2011). Quantitative assessment and spatial characteristics analysis of agricultural drought vulnerability in China. Natural Hazards, 56(3), 785-801. 